To cite this article: Jennifer B. Cabaron and Richard R. Cabaron (2021). EVALUATION OF SUSTAINABLE BANKING PRACTICES IN THE PHILIPPINES, International Journal of Research in Commerce and Management Studies (IJRCMS) 3 (6): $189-203$

\title{
EVALUATION OF SUSTAINABLE BANKING PRACTICES IN THE PHILIPPINES
}

\author{
Jennifer B. Cabaron ${ }^{1}$ and Richard R. Cabaron ${ }^{2}$ \\ Jose Rizal Memorial State University \\ DOI: http://dx.doi.org/10.38193/IJRCMS.2021.3612
}

\begin{abstract}
This study aims to evaluate the sustainable banking practices of rural banks in the Philippines. Mean and standard deviation was used to determine the sustainable banking practices of 80 participating rural banks in 2019. The researcher utilized a modified questionnaire on sustainability practices with a Cronbach alpha value of 0.85 . The study revealed that rural banks were extensively practiced on social and economic; however, they were only sometimes practiced on the environmental aspects. These results indicate that rural banks look into their economic and social banking practices if they are sustainable and can be transformed into practices that will enable them to be sustainable over the long term. This is the first study that combined the three dimensions of sustainability practices of rural banks in the Philippines.
\end{abstract}

KEYWORDS: sustainable banking practices, social sustainability, environmental sustainability, economic sustainability

\section{INTRODUCTION}

The World Commission on Environment and Development (1987) initially defined the term sustainability as "meeting current requirements without jeopardizing future generations' ability to meet their demands" (WCED, 1987; Sikdar, 2003; Ameer \& Othman, 2012). Sustainability refers to building a society where an appropriate balance between economic, social, and environmental goals is developed (World Commission on Environment and Development, 1987; Zborkova, Dvorakova, 2011; Krechovská \& Procházková, 2014). The three dimensions-economic, social and environmentalhave to be satisfied, and this is called the triple bottom line coined in the 1990s by Elkington to achieve sustainable development goals. The triple bottom line describes an investment's economic, environmental, and social value that may accrue outside a firm's financial bottom line. It is related to the concept of sustainable development (Elkington, 2004; Hammer \& Pivo, 2016). Van Marrewijk (2003, cited in Kumar et al., 2019), sustainable business development not just by focusing on economic performance but also by delivering on environmental and social performance has become imperative for businesses across the world. 
For Gelder (2006, cited in Ramnarain and Pillay, 2016), sustainability in banking should be a seamless blend of corporate culture and endeavor for business, and operational innovation and excellence, and a socially responsible and customer-focused attitude goes beyond the necessary compliance requirements of being a sustainable bank. Middleton (2010), sustainable banking policies and practices of a bank could contribute substantially towards a prosperous, sustainable, and peaceful world for present and future generations that added benefit of minimizing their lending risk and increasing their profits from lending to emerging lucrative 'green' businesses.

Banks in ASEAN countries are making progress, but they still have a long way to go in terms of sustainability policy. The need for banks to bridge these gaps originates primarily from the urgent need to battle climate change and promote sustainable development. Still, it also stems from the rapidly changing global sustainable finance landscape (World Wide Fund Sustainable Finance Report, 2018). Kumar and Prakash (2019) stress that banking is vital to the worldwide economy. Various banking organizations' adoption of sustainable banking practices is a powerful engine for long-term development. Torreja (2003) and Aragon et al. (2011) classify commercial banks, thrift banks, rural banks, offshore banks, specialized government banks, and non-bank financial institutions are the most common financial institutions in the Philippines.

Aragon et al. (2011) defined the rural bank industry as a small portion of the Philippine financial system as a whole. They may seem insignificant from a monetary and fiscal policy perspective. Elkington (1997) and Schutten (2016), rural banks are assumed to have business models. Still, it is uncertain whether these models contain the dimensions of sustainability such as social, economic, and environmental. Alshehhi, Nobanee, and Khare (2018) concluded in their meta-analysis review that there is a need to examine the impact of three dimensions of sustainability, namely social, economic, and environmental. The study of Jan et al. (2019) concluded that improvement in sustainability practices would add financial values to the management, shareholder, and the market financial performance indicators of the Islamic banking industry across the world.

Further, this study anchored integrated theories of the sustainable banking business model of Elkington (1994), the Stakeholders Theory of Pirsch, Gupta \& Grau (2007), and the Natural-ResourceBased View (NRBV) of Hoopes, Madsen \& Walker (2003). These theories have been applied in various domains; they become the building blocks of sustainable practices in the banking industry. Further, these add to the body of knowledge as underpinning theories for evaluating the sustainable banking practices of rural banks in the Philippines. 


\section{MATERIALS AND METHODS}

\subsection{Sampling and population}

In the data from Bangko Sentral ng Pilipinas (BSP), 440 active rural banks are in the Philippines. Of 440 active rural banks, 121 rural banks publicly publish their financial statements (http://www.bsp.gov.ph/banking/psoc_rb).

The purposive sampling method was utilized to select one hundred-one (101) rural banks in the Philippines, which published their balance sheet as of March 31, 2019. The names of these rural banks were obtained from the BSP website.

The research participants of this investigation were determined using Sample Size to Estimate the Average, that is,

$$
n=z^{2} \sigma^{2} / E^{2}
$$

In this study, the researcher made use a $\pm 8 \%$. They are substituting these parameters to the above formula resulted in a minimum number of research respondents of 101. If the rural banks would not agree to participate in the study, at least $70 \%$ to $80 \%$ was the target sample size or $n=80$. The respondents of the study were the manager or the key officer who was most knowledgeable about the sustainability practices of the selected rural banks. They were given questionnaires to provide information on their sustainable banking practices, and or the researcher sent the survey through email as provided by the BSP website.

\subsection{Research Instruments}

A modified questionnaire was utilized to conduct the study for sustainable banking practices of selected rural banks in the Philippines. A modified questionnaire by Baumgartner and Ebner (2010) was used for the economic and social sustainability indicators. For environmental sustainability indicators, this study used the indicators by Jan, Marimuthu, bin Mohd, and Isa (2019).

The survey questionnaire focused on sustainable banking practices, including economic, environmental, and social dimensions. This questionnaire assessed the best practices that rural banks have implemented. Part of the survey questionnaire contains three aspects of sustainability. Each item corresponds to numeric scales with qualitative equivalents.

For the extent of the Sustainable Banking practices, namely: economic, environmental, and social, a five-point Likert scale was used (see Table 1). The instrument was pretested to 12 banking institutions with the same characteristics as the study's target population. It resulted in a Cronbach alpha value of 0.85 , which met the minimum reliability coefficient of at least 0.70 . It implies that a questionnaire is 
a tool with a very high-reliability index. For Nunnally (1978, cited in Wei and Lin, 2015), as the construct reliability of all scales exceeds the suggested value of 0.70 , this indicates acceptable internal consistency.

Table 1. Rating Scale and Interpretation for Sustainable Banking Practices

\begin{tabular}{|c|c|c|c|}
\hline $\begin{array}{l}\text { Rating } \\
\text { Scale }\end{array}$ & Weight & Description & Interpretation \\
\hline 5 & $4.21-5.0$ & $\mathbf{A P}$ & $\begin{array}{l}\text { Always Practiced (specific situation cited is } \\
\text { practiced five (5) times or every day in its } \\
\text { business operation). }\end{array}$ \\
\hline 4 & $3.41-4.20$ & OP & $\begin{array}{l}\text { Often Practiced (specific situation cited is } \\
\text { practiced four (4) times a week in its business } \\
\text { operation). }\end{array}$ \\
\hline 3 & $2.61-3.40$ & SoP & $\begin{array}{l}\text { Sometimes Practiced (specific situation cited } \\
\text { is practiced three (3) times a week in its } \\
\text { business operation). }\end{array}$ \\
\hline 2 & $1.81-2.60$ & SeP & $\begin{array}{l}\text { Seldom Practiced (specific situation cited is } \\
\text { practiced two (2) times a week in its business } \\
\text { operation). }\end{array}$ \\
\hline 1 & $1.00-1.80$ & NP & $\begin{array}{l}\text { Not Practiced (specific situation cited is not } \\
\text { practiced at all in its operation basis). }\end{array}$ \\
\hline
\end{tabular}

\subsection{Data Analysis}

Based on the problems set in the study, the extent of practice on the dimensions of sustainable banking along with economic, environmental, and social used the mean and standard deviation. After all the data were collected, these were checked for non-response. Follow-up was made for items of nonresponse to the rural banks involved. Final data from the 80 participating banks were encoded in Microsoft Excel for data management and imported to IBM-SPSS for final analysis. This researcher assumed that the managers answered the questionnaires truthfully and to the best of their knowledge and abilities. 


\section{RESULTS AND DISCUSSION}

\section{Table 2. Sustainable Economic Banking Practices of Selected Rural Banks in the Philippines}

\begin{tabular}{|c|c|c|c|}
\hline Practices & $M$ & $S D$ & Interpretation \\
\hline $\begin{array}{l}\text { 1. Clear processes and roles are } \\
\text { defined so that business } \\
\text { activities are efficiently } \\
\text { conducted, and every } \\
\text { employee knows what the } \\
\text { organization expects from him } \\
\text { or her (also concerning } \\
\text { sustainability). }\end{array}$ & 4.11 & 0.60 & Often Practiced \\
\hline $\begin{array}{l}\text { 2. Makes method to plan, } \\
\text { develop, organize, maintain, } \\
\text { transfer, apply, and measures } \\
\text { specific knowledge and } \\
\text { improve the organizational } \\
\text { knowledge base. }\end{array}$ & 4.09 & 0.58 & Often Practiced \\
\hline $\begin{array}{l}\text { 3. Uses of BAT (Best Available } \\
\text { Techniques) and integrated } \\
\text { environmental technologies, } \\
\text { concentrating on cleaner } \\
\text { production and zero-emission } \\
\text { technologies. }\end{array}$ & 3.98 & 0.76 & Often Practiced \\
\hline $\begin{array}{l}\text { 4. Integration of sustainability } \\
\text { into daily business life. }\end{array}$ & 3.93 & 0.65 & Often Practiced \\
\hline $\begin{array}{l}\text { 5. Makes effort in sustainability- } \\
\text { related Research \& Design to } \\
\text { reduce the environmental } \\
\text { impacts of new products and } \\
\text { business activities. }\end{array}$ & 3.91 & 0.89 & Often Practiced \\
\hline $\begin{array}{l}\text { 6. Works in shared programs and } \\
\text { networks on the development } \\
\text { of innovative products and } \\
\text { technologies. }\end{array}$ & 3.91 & 0.68 & Often Practiced \\
\hline $\begin{array}{l}\text { 7. Relationships with suppliers, } \\
\text { with a focus, are also placed } \\
\text { on sustainability. }\end{array}$ & 3.88 & 0.70 & Often Practiced \\
\hline $\begin{array}{l}\text { 8. Cooperates and actively } \\
\text { collaborates with various } \\
\text { partners (e.g., suppliers, R\&D } \\
\text { institutions, universities). }\end{array}$ & 3.80 & 0.75 & Often Practiced \\
\hline $\begin{array}{l}\text { 9. Adaptations of process } \\
\text { management to achieve } \\
\text { sustainability necessitates the }\end{array}$ & 3.76 & 0.73 & Often Practiced \\
\hline
\end{tabular}


systematic implementation of corporate sustainability.

10. Makes activities and approaches that keep knowledge related to sustainability in the organization.

11. Consideration of issues related to sustainability in purchasing. Awareness and consideration of issues related to sustainability in the organization, as well as throughout the supply chain.

12. Inclusion of issues related to sustainability in company reports, either in individual sustainability reports or integrated with corporate reports.
$3.74 \quad 0.81 \quad$ Often Practiced

Often Practiced

$3.63 \quad 0.86 \quad$ Often Practiced

$\begin{array}{lll}3.86 & 0.49 & \text { Often Practiced }\end{array}$

\section{The Extent of Sustainable Economic Banking Practices}

Table 2 shows the extent of sustainable economic banking practices of the selected rural banks in the Philippines. The Grand Mean is $3.86(S D=.49)$, which means the items in the survey questionnaire are on average, "Often Practiced," as listed in Table 2. It can be noted that rural banks have often practiced economic activities that can lead to economic sustainability.

For instance, item 1 states: "Makes effort in sustainability-related Research \& Design to reduce the environmental impacts of new products and business activities," and this got a mean score of 3.91 $(S D=.89)$, which means "Often Practiced." This is very noteworthy since environmental Research \& Design can reduce the environmental impacts of the rural banks' new products and business activities. Based on Amini and Bienstock (2014) study, the most sophisticated organizations that embrace ecological-environmental sustainability initiatives include developing and manufacturing products from renewable resources and reducing the use of resources in their manufacturing process. Reducing resources lead to cost savings in organizations. Another item got a mean rating of $4.11(S D=.60)$, the highest among the items under sustainable economic banking practices. It states, "Clear processes and roles are defined so that business activities are efficiently conducted, and every employee knows what the organization expects for sustainability." Again, this is about the economic sustainability of the rural bank. Wolf (2014) believes that it is essential to clearly define the responsibility of its employees for sustainability activities. Such employees can act as vital multipliers in sustainability thinking 
within a firm. With this, they will play a key role in spreading knowledge and experience on sustainability throughout the organization.

Generally, Bahadur and Waqqas, (2013), according to Profits, cost savings, economic growth, research, and development in an organization are an economic dimension of sustainability. The profit characteristic needs to be considered by a firm as the real economic benefit of society. When the financial aspect is integrated into the social aspect (economic-social elements), they develop business ethics, fair trade, and worker rights.

The authors say that sustainable economic banking practices are related to the profit goal of organizations, particularly the rural banks involved in this study. The future economic growth of the rural banks will rely significantly on how well they integrate sustainable economic banking practices into their daily operations.

\section{The Extent of Sustainable Environmental Banking Practices}

Table 3 shows the sustainable environmental banking practices of the selected rural banks in the Philippines. It can be noted that the Grand Mean is $2.90(S D=.83)$, giving a verbal interpretation of "Sometimes Practiced." It implies that rural banks do not have extensive practice for environmental sustainability. From the responses to the items in Table 2, it can be gleaned that all of the environmental practices except one got "Sometimes Practiced."

It indicates that the environmental awareness of the rural banks needs to be raised to a level where they will often practice rather than sometimes practice, or worse, seldom practice as in the case of one item getting "Seldom Practiced" mean response from the 80 banks. This is about water recycling and re-using that was seldom practiced with a mean of $2.44(S D=1.02)$.

Table 2. Sustainable Environmental Banking Practices of Selected Rural Banks

\begin{tabular}{llcc}
\hline \multicolumn{1}{c}{ Practices } & $M$ & $S D$ & Interpretation \\
\hline 1. $\begin{array}{l}\text { Reporting on compliance with } \\
\text { laws for the environment in the } \\
\text { annual report of the bank. }\end{array}$ & 3.34 & 0.95 & Sometimes Practiced \\
2. $\begin{array}{l}\text { Reporting about waste } \\
\text { management techniques } \\
\text { applied to the papers and IT } \\
\text { products used by the banks. }\end{array}$ & 3.30 & 4.48 & Sometimes Practiced \\
3. & & & \\
$\begin{array}{l}\text { Reporting about the total } \\
\text { environmer of grievances about }\end{array}$ & 3.08 & 0.87 & Sometimes Practiced \\
\hline
\end{tabular}


addressed, and resolved through a formal grievance mechanism.

4. Reporting about the total weight and volume of the material used, and the percentage of material recycled.

5. Reporting about how the environmental impacts of transporting the bank's members/workforce, and other goods and services are mitigated.

6. Reporting about new suppliers that were screened using environmental criteria.

7. Reporting about methodologies used for the reduction of energy consumption.

8. Total environmental expenditure by type.

Sometimes Practiced

$2.99 \quad 0.86 \quad$ Sometimes Practiced

2.96

Sometimes Practiced

Sometimes Practiced

2.78

1.01

Sometimes Practiced

9. Reporting about habitat protected or restored due to green investment

10. The extent of impact mitigation of environmental impacts of banks products and services.

11. Accounting for the greenhouse gas emission resulting from the business travel and the courier services of banks.

12. The total volume of water recycled and reused by the banks.

0.98

Sometimes Practiced

0.98

Sometimes Practiced

Sometimes Practiced

Seldom Practiced

Grand Mean
0.83

Sometimes Practiced

It can likewise be gleaned that waste management techniques, environmental impact mitigation, and environmental reporting are sometimes practiced. The rural banks also sometimes practiced habitat protection and engagement in green investments that pertain to their community responsibility and socially responsible investing. According to UNEP-FI (2007) and Dlamini (2011), banks provide loans to thousands of businesses and individuals, and ultimately, by including environmental sustainability factors in credit risk management. Also, banks can allocate finance to mitigate the 
negative impacts on the environment and influence businesses to manage the environment responsibly. In the investigation of Dlamini, (2011), the practices adopted by the banks to pursue environmental sustainability are currently internally focused with priority for quick operational wins addressing risk and cost reduction.

The selected rural banks sometimes practiced screening their suppliers for green management or have eco-certification from DENR as green suppliers. It is important because all those stakeholders in the supply chain should be engaged in environmental conservation and protection as mandated by environmental laws in the country. Based on the rural banks' responses to environmental banking practices, green banking, there is a need to improve these practices to make them environmentally sustainable. Lastly, according to Bihari (2011) and Islam and Das, (2013), green banking includes promoting corporate social responsibility (CSR). The bank starts to protect the environment they consider before financing a project, whether it is environment-friendly, which has any implications for the future. A company's borrower will be given a loan only when all the environmental safety standards are followed.

Table 4. Sustainable Social Banking Practices of Selected Rural Banks

\begin{tabular}{|c|c|c|c|}
\hline Practices & $M$ & $S D$ & Interpretation \\
\hline $\begin{array}{l}\text { 1. Behaving fairly on the market } \\
\text { and avoiding manipulating } \\
\text { business practices. This } \\
\text { includes no rule-breaking, no } \\
\text { price-fixing or joining a } \\
\text { cartel, and no corruption for } \\
\text { gaining an advantage. }\end{array}$ & 4.23 & 0.53 & Always Practiced \\
\hline $\begin{array}{l}\text { 2. Support of stakeholders (and } \\
\text { others) and their issues on } \\
\text { regional/ national level. }\end{array}$ & 4.20 & 0.46 & Often Practiced \\
\hline $\begin{array}{l}\text { 3. Participation or creation of } \\
\text { sustainability-related } \\
\text { activities for the local } \\
\text { community. }\end{array}$ & 4.19 & 0.48 & Often Practiced \\
\hline $\begin{array}{l}\text { 4. Guarantee that no health and } \\
\text { safety risks occur when } \\
\text { working in/for the } \\
\text { organization. }\end{array}$ & 4.15 & 0.45 & Often Practiced \\
\hline $\begin{array}{l}\text { 5. Operation of programs for } \\
\text { employees to prevent dangers } \\
\text { and to stay generally fit and } \\
\text { healthy. }\end{array}$ & 4.15 & 0.48 & Often Practiced \\
\hline $\begin{array}{l}\text { 6. Transparency in all its } \\
\text { activities to ameliorate }\end{array}$ & 4.14 & 0.47 & Often Practiced \\
\hline
\end{tabular}


relationships towards its stakeholders.

7. Awareness of needs, claims, and motivation factors of employees to implement sustainability sufficiently into the organization due to support of management for acting sustainably (e.g. time, money, resources).

8. The bank develops human capital for sustainabilityrelated issues through specific programs such as permanent education, mentoring, or training.

9. Allocates regarding sustainability, important elements are a culture of respect, fair rules and behavior within an organization (and between its subsidiaries) and fair wealth/profit allocation, as well as serious consideration of stakeholders' ideals.

10. Active involvement and exemplary function of management on sustainability topics for employees.

11. The bank develops incentives and reward systems (monetary, non-monetary) for the employees.

12. Broad cross-working education (job enrichment, job enlargement) to become aware of the different challenges and issues of corporate sustainability.

13. Gives insight into all relevant data; following rules of (stock) markets on corporate governance and defining responsibilities and behavior of the board.
$4.14 \quad 0.50 \quad$ Often Practiced

$4.14 \quad 0.55 \quad$ Often Practiced

$4.11 \quad 0.50 \quad$ Often Practiced

$4.11 \quad 0.62 \quad$ Often Practiced

$4.11 \quad 0.64 \quad$ Often Practiced

$4.11 \quad 0.57 \quad$ Often Practiced

$4.10 \quad 0.65 \quad$ Often Practiced 


\begin{tabular}{|c|c|c|c|}
\hline $\begin{array}{l}\text { 14. Ethical behavior towards } \\
\text { sustainability consists of } \\
\text { well-established, basic } \\
\text { assumptions and principles } \\
\text { relating to the cooperation } \\
\text { within an organization and } \\
\text { the behavior towards } \\
\text { (external) stakeholders. }\end{array}$ & 4.09 & 0.56 & Often Practiced \\
\hline $\begin{array}{l}\text { 15. No use or sale of own assets } \\
\text { and goods for non- } \\
\text { sustainable activities. }\end{array}$ & 3.58 & 0.82 & Often Practiced \\
\hline Grand Mean & 4.10 & 0.40 & Often Practiced \\
\hline
\end{tabular}

\section{The Extent of Sustainable Social Banking Practices}

Table 4 shows the extent of sustainable social banking practices of the selected rural banks in the Philippines. The Grand Mean is $4.10(S D=.40)$, which is interpreted as "Often Practiced." It is a noteworthy rating since sustainable social banking practices will benefit all stakeholders of the rural banks, in particular, fulfilling their Corporate Social Responsibility (CSR) to the community where they are located and to the bigger society in general.

For instance, they rated quite high $(M=4.14, S D=.50)$ this statement, "Awareness of needs, claims and motivation factors of employees to implement sustainability sufficiently into the organization due to support of management for acting sustainably (e.g., time, money, resources). Social sustainability concerns banking practices that sustainably support the bank's management in terms of time, money, and resources. Time should not be wasted on activities that do not contribute to corporate social sustainability. Also, money spent on sustainably managing the bank will redound the benefits of the employees through an increase in their salaries because of cost savings. In terms of bank resources, human and financial resources, these can be managed efficiently and sustainably through the cooperation of everyone in the organization.

The statement, "The bank develops human capital for sustainability-related issues through specific programs such as permanent education, mentoring or training," likewise captures the banks' social banking practices in terms of sustaining their human capital. It is noteworthy that bank employees are the organization's assets, and developing them along the various dimensions of corporate sustainability will ensure that employees contribute to the bank's success and sustainability.

Likewise, the statement, "Behaving fairly on the market and avoiding manipulating business practices. It includes no rule-breaking, no price-fixing or joining a cartel, and no corruption for gaining an advantage" highly rated by the rural banks $(M=4.23, S D=.53)$, which is interpreted as 
"Always Practiced." This is an excellent banking social practice that is sustainable. It implies that the banks are having ethical behavior and can be relied upon by their clients.

As Liang, Chang, and Shao, (2018) pointed out that Corporate Social Responsibility (CSR) is particularly important in the banking sector because banks generate profits primarily by granting individual and business loans out of funds raised mainly from deposits by the general public. In the study of Sheremenko, Escalante, and Florkowski, (2017), poverty outreach is improved by servicing small loans to more borrowers, particularly women. The literature says that the social practice of Corporate Social Responsibility (CSR) of banks is considered part of their sustainable social banking practices. These activities reach out to the poorer sectors of society, which is part of rural banks' mission to alleviate poverty through their loan services to the agricultural industry.

\section{Summary on the Sustainable Banking Practices}

Table 5. Summary on the Sustainable Banking Practices of Selected Rural Banks in the Philippines

\begin{tabular}{lccc} 
Sustainable Banking Practices & $M$ & $S D$ & Interpretation \\
\hline Social Practices & 4.10 & 0.40 & Often Practiced \\
Economic Practices & 3.86 & 0.49 & Often Practiced \\
Environmental Practices & 2.90 & 0.83 & Sometimes Practiced \\
\hline
\end{tabular}

Table 5 shows the overall summary of the extent of Sustainable Banking Practices of rural banks. The highest mean is on Social Practices at $4.10(S D=.40)$, followed by Economic Practices $(M=$ $3.86, S D=.49$ ) interpreted as "Often Practiced," while the lowest mean is on environmental practices $(M=2.90, S D=.83)$ interpreted as "Sometimes Practiced." The results imply that rural banks are active in practicing sustainable social banking practices. Based on an interview from one of the managers in rural banks, their bank offers an agricultural loan to the farmers with collateral of original land title. This is an indication that rural banks are engaged in helping the agricultural communities to avail of loans for their farm needs. Or the banks are active in their Corporate Social Responsibility (CSR), where they can assist the people of the rural communities in improving their lives through the social services of the banks.

Sheremenko, Escalante, and Florkowski (2017), based on the literature reviews, consider the social practice of Corporate Social Responsibility (CSR) of banks as part of their sustainable social banking practices. These activities reach out to the poorer sectors of society, which is part of rural banks' 
mission to alleviate poverty through their loan services to the agricultural industry.

\section{CONCLUSION AND RECOMMENDATION}

Based on the findings of the study, the rural banks often practiced sustainable economic banking practices. This is expected because this is the core activity of the bank - the economic sustainability will rest on how they generate deposits, earn interest income from loans, and expand their portfolio. Thus, they often practiced sustainable economic banking practices. The sustainable environmental banking practices got the smallest rating, interpreted as "Sometimes Practiced." As discussed earlier in this paper, the activities involved certain activities that might limit their choices, like not accepting borrowers whose business loans will be used to produce products that loans pollute the environment. Ideally, the banks should practice this screening often rather than sometimes, but it has a loss of profit implications. However, it has to be noted that screening suppliers based on environmental criteria is a good management practice, but will limit the banks' choices in terms of suppliers to deal with. There is still a need to raise the banks' environmental awareness on protecting the Planet through sustainable environmental banking practices in place and well-functioning in every rural bank.

Thus, the researcher recommends for the rural banks to look into their economic and social banking practices if they are sustainable and can be transformed into practices that will enable them to be sustainable over the long term. For the rural banks to improve more on their environmental banking practices to change from "Sometimes Practiced" to at least, "Often Practiced," and much better if these sustainable environmental practices are always practiced.

\section{REFERENCES}

Alshehhi, A., Nobanee, H., \& Khare, N. (2018). The impact of sustainability practices on corporate financial performance: Literature trends and future research potential. Sustainability, 10(2), 494.

Ameer, R., \& Othman, R. (2012). Sustainability practices and corporate financial performance: A study based on the top global corporations. Journal of Business Ethics, 108(1), 61-79.

Amini, M., \& Bienstock, C. C. (2014). Corporate sustainability: an integrative definition and framework to evaluate corporate practice and guide academic research. Journal of Cleaner Production, 76, 12-19.

Aragon, J. Y., Kakinaka, M., \& Kim, D. (2011). Capital requirements of Rural Banks in the Philippines. Bangko Sentral Review, 2011, 27-40.

Bahadur, W., \& Waqqas, O. (2013). Corporate social responsibility for a sustainable business. Journal of Sustainable Society, 2(4), 92-97.

Bihari, S. C. (2010). Green banking-towards socially responsible banking in India. International 


\section{Journal of Business Insights \& Transformation, 4(1).}

Dlamini, T. H. (2011). The banking sector's response to environmental sustainability (Doctoral dissertation, University of Pretoria).

Elkington, J. (1994). Towards the sustainable corporation: Win-win-win business strategies for sustainable development. California management review, 36(2), 90-100.

Elkington, J. (2004). Enter the triple bottom line in Henriques, A. and Richardson, J. (Eds); The Triple Bottom Line: Does It All Add up. Earth scan, UK.

Gelder, J. W. V. (2006). The do's and don 'ts of Sustainable Banking-A Bank Track manuall, BankTrack.

Hammer, J., \& Pivo, G. (2016). The triple bottom line and sustainable economic development theory and practice. Economic Development Quarterly, 31(1), 25-36.

Hoopes, D. G., Madsen, T. L., \& Walker, G. (2003). Guest editors' introduction to the special issue: why is there a resource-based view? Toward a theory of competitive heterogeneity. Strategic management journal, 24(10), 889-902.

Islam, M. S., \& Das, P. C. (2013). Green banking practices in Bangladesh. IOSR Journal of Business and Management, 8(3), 39-44.

Jan, A., Marimuthu, M., bin Mohd, M. P., \& Isa, M. (2019). The nexus of sustainability practices and financial performance: From the perspective of Islamic banking. Journal of Cleaner Production, 228, 703-717.

Kumar, K., \& Prakash, A. (2019). Developing a framework for assessing sustainable banking performance of the Indian banking sector. Social Responsibility Journal.

Krechovská, M., \& Procházková, P. T. (2014). Sustainability and its integration into corporate governance focusing on corporate performance management and reporting. Procedia Engineering, 69, 1144-1151.

Middleton, C. (2010). Thailandâ€ $€^{\mathrm{TM}}$ s Commercial Banksâ€ $€^{\mathrm{TM}}$ Role in Financing Dams in Laos and the Case for Sustainable Banking (No. id: 3223).

Pirsch, J., Gupta, S., \& Grau, S. L. (2007). A framework for understanding corporate social responsibility programs as a continuum: An exploratory study. Journal of business ethics, 70(2), 125-140.

Ramnarain, T. D., \& Pillay, M. T. (2016). Designing Sustainable Banking Services: The Case of Mauritian Banks. Procedia-Social and Behavioral Sciences, 224, 483-490.

Schutten, W. (2016). Sustainable banking business models (Master's thesis, University of Twente) 
Sheremenko, G., Escalante, C. L., \& Florkowski, W. J. (2017). Financial sustainability and poverty outreach: The case of microfinance institutions in Eastern Europe and Central Asia. The European Journal of Development Research, 29(1), 230-245.

Sikdar, S. K. (2003). Sustainable development and sustainability metrics. AIChE journal, 49(8), 1928-1932.

Van Marrewijk, M. (2003). Concepts and definitions of CSR and corporate sustainability: Between agency and communion. Journal of business ethics, 44(2), 95-105.

WCED, S. W. S. (1987). World commission on environment and development. Our common future, 17(1), 1-91.

Wolf, J. (2014). The relationship between sustainable supply chain management, stakeholder pressure and corporate sustainability performance. Journal of business ethics, 119(3), 317-328. 